\title{
MATA KULIAH KEWIRAUSAHAAN ISLAM DAN LINGKUNGAN PENGARUHNYA TERHADAP PEMBENTUKAN KARAKTER MAHASANTRI PRENEUR DI PERGURUAN TINGGI BERBASIS PESANTREN
}

\author{
Husnul Khatimah * \\ Sekolah Tinggi Ilmu Bahasa Arab (STIBA) Ar Raayah Sukabumi, Indonesia \\ Nuradi \\ Sekolah Tinggi Ilmu Bahasa Arab (STIBA) Ar Raayah Sukabumi, Indonesia
}

\begin{abstract}
This study aims to determine the extent of how the Islamic entrepreneurship and environment course at pesantren based colleges are able to build the character of preneur students. The research method is a quantitative descriptive method with data analysis techniques of SPLS3 which is an alternative method of SEM to analyze how the influence of Islamic entrepreneurship and environment course on the formation of preneur students' characters. The population in this study was 33 students of the Islamic Broadcast Communication Study Program of STIBA Ar Raayah Sukabumi, with the sample also 33 students but the one who filled out the questionnaires only 28 students which consist of 9 male students and 19 female students. The data collection technique is saturated sampling technique, which is a sampling technique using all population numbers as the respondents through a google form questionnaire. The results showed that the Islamic entrepreneurship course had no significant effect on the formation of the character of mahasantri preneur, this indicates that we need innovation in the learning process in this course. On the other hand, the environment has a great influence, this is because mahasantri always interact with asatidzah (lecturers) who run a business in their daily lives.
\end{abstract}

JEL : A22, I20, M20.

Keywords : islamic entrepreneurship, environment, mahasantri, college, pesantren.

\begin{abstract}
ABSTRAK
Penelitian ini bertujuan untuk mengetahui sejauh mana mata kuliah kewirausahaan Islam dan lingkungan pada perguruan tinggi berbasis pesantren mampu membentuk karakter mahasantri preneur. Metode penelitian yang digunakan adalah metode deskriptif kuantitatif dengan teknik analisis data SPLS3 yang merupakan salah satu metoode alternatif SEM untuk menganalisis bagaimana pengaruh mata kuliah kewirausahaan Islam dan lingkungan terhadap terbentuknya karakter mahasantri preneur. Populasi dalam penelitian ini sejumlah 33 mahasantri Prodi Komunikasi Penyiaran Islam STIBA Ar Raayah Sukabumi, dengan sampel juga sebanyak 33 orang akan tetapi yang mengisi kuesioner hanya sejumlah 28 orang yang terdiri dari 9 mahasantriwan dan 19 mahasantriwati. Teknik pengambilan data berupa teknik sampling jenuh yang merupakan teknik pengambilan sampel dengan menggunakan semua jumlah populasi sebagai responden melalui kuesioner google form. Hasil penelitian menunjukkan bahwa mata kuliah kewirausahaan Islam tidak berpengaruh signifikan terhadap pembentukan karakter mahasantri prenenur, hal ini menunjukkan bahwa perlu ada inovasi dalam proses pembelajaran dalam mata kuliah ini. Sebaliknya, lingkungan memiliki pengaruh yang besar, hal ini dikarenakan para mahasantri dalam kesehariannya selalu berinteraksi dengan para asatidzah atau dosen yang pada umumnya menjalankan usaha.
\end{abstract}

Kata Kunci : kewirausahaan islam, lingkungan, mahasantri, perguruan tinggi, pesantren.

\section{PENDAHULUAN}

Pengangguran merupakan salah satu masalah yang membutuhkan perhatian serius di Indonesia. Kondisi ini semakin parah dengan terjadinya pemutusan hubungan kerja akibat krisis global yang melanda berbagai belahan dunia, sehingga pemerintah menerapkan berbagai strategi

*Email : husnul.khatimah@arraayah.ac.id

Received : 29-03-2021, Accepted : 28-12-2021, Published : 28-12-2021

P-ISSN : 2087-9954, E-ISSN : 2550-0066. DOI : http://dx.doi.org/10.26418/jebik.v10i3.45961 
untuk menekan populasi pengangguran dengan menambah jumlah wirausahawan, di antaranya dengan mewajibkan mata kuliah kewirausahaan dalam kurikulum pendidikan mulai dari tingkat dasar sampai perguruan tinggi kepada seluruh peserta didiknya (Febrianto, 2013; Taufik \& Akmal, 2018; Aidha, 2016).

Konsep pendidikan kewirausahaan seharusnya tidak hanya diberikan dalam bentuk landasan teoritis, namun juga mampu membentuk mindset (pola pikir) dan karakter entrepreneur (wirausahawan), sebagaimana dikemukakan oleh Ranto (2017). Menyikapi hal tersebut maka perguruan tinggi sebaiknya mengambil langkah strategis melalui pembangunan paradigma baru dalam pembelajaran dasar kewirausahaan (Mustafa, Bistamam, Arep, Latip \& Jais, 2019). Dengan demikian diharapkan output perguruan tinggi tidak hanya berorientasi untuk menghasilkan lulusan job seeker (pencari kerja) tetapi mampu menciptakan alumni job creator (menciptakan lapangan kerja) (Sharaf, El-Gharbawy \& Ragheb, 2018) serta memiliki karakter wirausahawan yang kuat dengan penggunaan teknologi digital (Prastyaningtyas \& Arifin, 2019)

Munif \& Baharun (2018) serta Maisaroh (2019) mengemukakan pesantren merupakan lembaga yang telah lama berperan dalam pembentukan moral dan tonggak pembangunan bangsa sejak era penjajahan hingga masa kini seperti yang banyak diuraikan dalam catatan sejarah. Sejalan dengan perkembangan zaman lembaga keislaman ini juga bertransformasi dari sistem tradisional ke modern termasuk konsep pendidikannya yang memasukkan jenjang mulai dari pendidikan dasar hingga pendidikan tinggi. Berbicara tentang perguruan tinggi berbasis pesantren bukanlah merupakan hal yang baru, karena konsep kampus dalam pesantren atau pesantren dalam kampus telah terlebih dahulu diselenggarakan sejak tahun 90-an oleh UNIDA Gontor yang dulu dikenal dengan nama ISID Gontor Ponorogo pada tahun 1995 dan UIN Malang pada tahun 1998 (Setyawan, 2016).

Fauzia (2019) mengatakan bahwa Islam sangat menekankan umatnya untuk menjalankan usaha (entrepreneur), melalui perintah Allah dan Rasulnya. Banyak nash dalam al-Quran dan asSunnah yang memerintahkan untuk berwirausaha dengan cara yang baik dan halal untuk meraih falah di dunia dan akhirat. Praktek wirausaha sudah dicontohkan oleh Rasulullah Shallallahu 'Alaihi Wasallam beserta para sahabatnya di antaranya yang kita kenal Abdurrahman bin 'Auf, Ustman bin Affan, Khadijah binti Khuwailid istri beliau Radhiyaallahum Ajma'in, mereka semua adalah para pedagang yang sukses (Muliana, 2017). Allah Subhanahu Wa Ta'ala berfiman dalam Quran Surah al-Jumu'ah ayat 10:

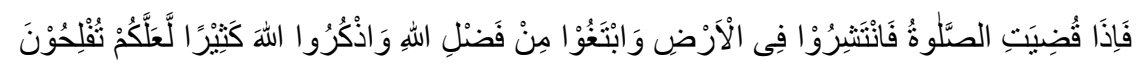

"Apabila salat telah dilaksanakan, maka bertebaranlah kamu di bumi; carilah karunia Allah dan ingatlah Allah banyak-banyak agar kamu beruntung".

Dalam hadist yang dikeluarkan oleh Imam Al Bukhari No. 1966 dalam Shahih-nya:

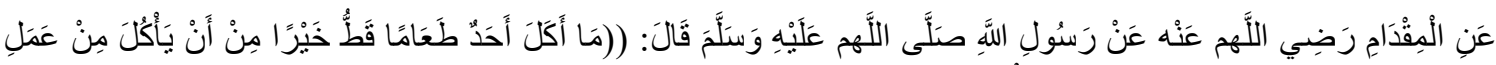

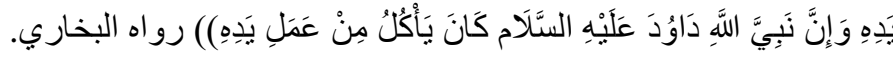

Dari al-Miqdam Radhiyallahu 'anhu, bahwa Rasulullah shallallahu 'alaihi wasallam bersabda: "Tidaklah seorang (hamba) memakan makanan yang lebih baik dari hasil usaha tangannya (sendiri), dan sungguh Nabi Dawud 'alaihissalam makan dari hasil usaha tangannya (sendiri)". 
Pondok pesantren dengan lingkungan dan sistem pendidikan yang melatih sikap kemandirian menghasilkan santri atau dalam hal ini mahasantri atau mahasiswa yang memiliki karakter mandiri, sebuah kepribadian yang menjadi modal dasar seorang entrepreneur, meski pada prakteknya lulusan pondok pesantren masih sedikit yang menggeluti profesi sabagai wirausahawan (Kamal \& Thoyyibah, 2020). Adanya penambahan mata kuliah pendidikan entrepreneur di pondok pesantren diharapkan dapat merubah sebagian pandangan masyarakat tentang pesantren, yang mengatakan bahwa anak yang masuk ke pesantren akan menjadi anak yang masa depannya suram karena di pesantren mereka hanya akan diajarkan ilmu akhirat dan tidak diajarkan ilmu tentang dunia.

Di antara ruang lingkup pendidikan kewirausahaan, yaitu karakter, konsep, dan keterampilan yang harus diterapkan dalam program pembinaan kewirausahaan santri dengan ditunjang materi yang meliputi, konsep dasar kewirausahaan; jiwa dan sikap wirausaha; pengembangan kreatifitas; pengembangan ide usaha; penyusunan rencana usaha; memulai dan mengembangkan bisnis; dan keterampilan teknis kewirausahaan, sebagaimana dipaparkan oleh (Widodo \& Nugroho, 2014). Setelah pemberian materi pendidikan kewirausahaan di atas ditambah lagi dengan dukungan dari berbagai pihak maka sangat besar kemungkinan mahasantri di pondok pesantren akan tertarik untuk memulai berwirausaha.

Beberapa penelitian terkait menunjukkan bahwa adanya mata kuliah kewirausahaan berpengaruh positif terhadap peningkatan minat dan jiwa berwirausaha mahasiswa (Ramadhani \& Nurnida, 2017; Taufik \& Akmal, 2018). Penelitian lainnya menunujukkan bahwa minat berwirausaha mahasiswa Program Studi Manajemen Fakultas Ekonomi Universitas Kadiri sangat tinggi yang dipengaruhi oleh faktor inovasi, kreatifitas, dan teknologi (Rahmadi \& Heryanto, 2016), sedangkan menurut Kamal \& Thoyyibah (2020) media sosial, intelegensi, kepribadian dan motivasi pribadi berpengaruh positif terhadap lahirnya minat berwirausaha santri di pondok pesantren. Begitu pula halnya dengan lingkungan memiliki pengaruh terhadap keputusan untuk berwirausaha (Rahmadi \& Heryanto, 2016; Praswati, 2014; dan Koranti, 2013).

Penelitian ini berbeda dengan kajian yang ada sebelumnya karena berfokus pada mata kuliah kewirausahaan Islam dan lingkungan dengan prinsip aturan syariat yang melingkupinya dan bagaimana pengaruhnya terhadap pembentukan karakter mahasantri preneur pada perguruan tinggi berbasis pesantren, sedangkan penelitian lain hanya menekankan pada ruang lingkup mata kuliah kewirausahaan saja atau hanya befokus pada faktor lingkungan saja dan bagaimana melahirkan minat dan motivasi berwirausaha mahasiswa di perguruan tinggi.

\section{KAJIAN LITERATUR}

\subsection{Kewirausahaan Islam}

Sugita \& Ansori (2018) dan Dumasari (2014) menguraikan bahwa kewirausahaan merupakan sikap keberanian dalam diri seseorang sehingga memiliki kemampuan untuk merubah peluang yang ada menjadi sesuatu yang nyata dan bernilai berdasarkan ide yang kreatif, inovatif dan berani mengambil resiko, seperti yang juga dipaparkan oleh Saragih (2017) dan Jumaedi (2012), sedangkan kewirausahaan Islam merupakan suatu usaha yang dilandasi amal shalih dalam memanfaatkan sumber daya yang ada berupa aktivitas jual beli berlandaskan pada al-Quran dan as-Sunnah (Fauzia, 2019; Mufti, 2016; Bahri, 2018). 


\subsection{Materi Mata Kuliah Kewirausahaan Islam}

Proses sistematis dan kontinyu dalam bentuk formal atau informal untuk melahirkan manusia berjiwa wirausaha merupakan tujuan dari pendidikan kewirausahaan, yang bukan hanya berupaya membentuk karakter wirausaha namun juga memiliki kemampuan meningkatkan bakat serta skill, bahkan menciptakan sesuatu yang punya values sehingga dapat dimanfaatkan oleh seorang individu atau masyarakat dalam menjalankan usahanya (Rinawiyanti \& Gunawan, 2017; Susilaningsih, 2015). Selain itu, pendidikan kewirausahaan juga sepatutnya dimulai dari lingkungan keluarga, didikan dan teladan dari orang tua diharapkan mampu memberikan pengaruh positif dan membentuk karakter entrepreneur dalam diri anak (Periera, Mashabi \& Muhariati, 2017).

Sekolah Tinggi Ilmu Bahasa Arab (STIBA) Ar Raayah merupakan perguruan tinggi berbasis pesantren yang juga menyelenggarakan mata kuliah kewirausahaan Islam pada mahasantriwan dan mahasantriwati semester 5 Program Studi Komunikasi Penyiaran Islam (KPI) dengan bobot 3 SKS dengan menggunakan buku pedoman berjudul Islamic entrepreneurship kewirausahaan berbasis pemberdayaan (Fauzia, 2019), yang memuat materi (a) kewirausahaan Islam; (b) mengidentifikasi karakter kewirausahaan; (c) berubah menjadi lebih baik; (d) menjadi wirausahawan kreatif; (e) menemukan gagasan dan membangun sebuah usaha; (f) berusaha secara halal; (g) modal dan pembiayaan usaha; (h) pemasaran usaha baru; (i) pemasaran secara online; (j) pengelolaan keuangan usaha; (k) pengelolaan risiko usaha; (l) wirausahawan, kepemimpinan dan organisasi bisnis; (m) etika dalam kewirausahaan perspektif syariah; dan (n) zakat, infak, shadaqah dan wakaf dalam bisnis. Sebuah buku rujukan dalam mengawal mata kuliah kewirausahaan Islam yang menyajikan mulai dari bagaimana membentuk karakter wirausaha, mengelola keuangan dan risiko usaha, sampai kepada bagaimana membagi sebagian keuntungan yang diperoleh kepada pihak yang membutuhkan dalam bentuk ZISWAF berdasarkan prinsip syariah.

\subsection{Lingkungan}

Faktor atau kondisi lingkungan memperkuat terjadinya entrepreneurial process yang terdiri atas lingkungan fisik, lingkungan ekonomi, lingkungan kelembagaan (organisasi) dan lingkungan individu. Hasil penelitian menunjukkan bahwa anak yang terlahir dari orang tua yang bekerja sebagai wiraniagawan akan mengikuti jejak orang tuanya sebanyak lebih dari $50 \%$. Besarnya faktor lingkungan keluarga bisa dipahami secara logika bahwa anak yang dalam kesehariannya selalu berinteraksi dengan hal itu akan menciptakan motivasi tersendiri dalam diri mereka berupa motivasi berwirausaha ditambah lagi dengan kondisi keuangan keluarga yang dia nikmati sekarang itu merupakan hasil dari keluarganya yang telah melaksanakan wirausaha.

Lingkungan lembaga juga dapat berpengaruh terhadap lahirnya minat berwirausaha selain pengaruh role model lingkungan keluarga, contohnya adalah adanya suatu pesantren yang masyarakatnya atau civitasnya yang sukses berwirausaha. Hal ini bisa memberikan pengaruh positif ke para mahasantrinya. Sejalan dengan hal itu dalam suatu penelitian disampaikan bahwa di dalam lingkungan pondok pesantren yang para asatidzah, teman, dan para khirrij (alumni) yang sukses berwirausaha dapat mendorong para santri untuk menjadi entrepreneur (Kamal \& Thoyyibah, 2020). Kesimpulannya adalah karakter atau sifat setiap orang secara umum akan banyak ditentukan dan dipengaruhi oleh lingkungan sekitarnya, maka untuk menciptakan banyak 
entrepreneur muda atau mahasantri sudah selayaknya dibuatkan suatu lingkungan wirausaha sehingga semua orang bisa termotivasi.

Model peran, peluang aktifitas, pesaing, sumber daya, dan kebijakan pemerintah adalah faktor yang berasal dari environmental (lingkungan), yang merupakan salah satu dari beberapa faktor kritis yang berperan dalam melahirkan minat wirausaha, karena minat ini tidaklah dibawa sejak lahir melainkan berkembang mengikuti faktor yang mempengaruhinya (Suryana, 2014). Jiwa entrepreneur akan lebih mudah terbentuk dari dalam diri individu dan akan lebih efektif jika ditunjang dengan kegiatan yang berhubungan dengan faktor dari luar seperti pengaruh lingkungan (Haryani, 2017).

\subsection{Mahasantri sebagai Entrepreneur}

Risdiana (2014) mengemukakan bahwa amalan dalam mensyi'arkan dienul Islam disebut dengan istilah dakwah yang merupakan bentuk pengabdian kepada agama yang harus dijalankan dengan penuh keikhlasan tanpa mengharapkan balasan materi. Untuk itu, seorang mahasantri dalam mengemban amanah dakwah hendaknya memiliki kemandirian finansial di antaranya dengan menjalankan usaha sendiri atau yang dikenal dengan istilah mahasantri preneur. Mahasantri yang memiliki penghasilan dari wirausaha akan memberikan nilai tambah di tengah masyarakat. Hal ini dikarenakan mahasantri terlepas dari stigma sebagian masyarakat bahwa da'i atau ustadz menjadikan dakwah sebagai pekerjaan untuk mendapatkan uang, tentunya stigma ini akan hilang dengan sendirinya ketika para da'i tersebut memiliki penghasilan sendiri misalnya dari hasil berwirausaha.

Sikap yang harus dimiliki seorang mahasantri preneur, yang pertama yaitu berani memulai. Memulai usaha bukanlah hal yang mudah, dibutuhkan mental dan keberanian yang kuat, namun keuntungannya seorang mahasantri dapat menjadikan komunitas dakwahnya untuk mengenalkan usaha yang dijalankannya. Kedua adalah pantang menyerah. Kegagalan bisa saja terjadi dalam menjalankan usaha sehingga diperlukan sikap mental yang kuat dan pantang menyerah di dalamnya. Ketiga yaitu siap bekerja keras. Usaha yang baru dijalankan biasanya belum stabil, maka kerja keras dan dedikasi sangat penting dihadirkan dalam diri seorang mahasantri preneneur agar usaha tersebut dapat bertahan dan berkembang lebih baik lagi. Struktur model penelitian ini digambarkan sebagai berikut:

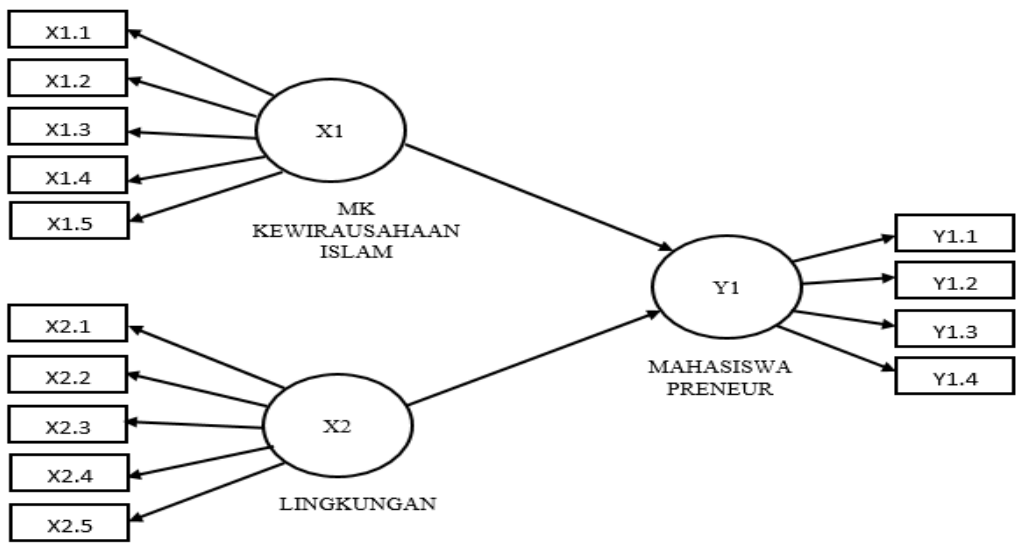

Gambar 1. Kerangka Penelitian 


\section{METODE PENELITIAN}

Populasi yang digunakan dalam penelitian ini sebanyak 33 orang, yaitu mahasantriwan sejumlah 13 orang dan mahasantriwati 20 orang, semester 5 Program Studi Komunikasi Penyiaran Islam Sekolah Tinggi Ilmu Bahasa Arab (STIBA) Ar Raayah Sukabumi yang memprogram mata kuliah kewirausahaan Islam yang diberikan angket penelitian. Jumlah responden yang tidak berpartisipasi sebanyak 5 orang sehingga total responden sebesar 28 orang, di antaranya 9 mahasantriwan dan 19 mahasantriwati. Teknik sampling jenuh merupakan teknik pengambilan sampel yang digunakan dalam penelitian ini, yaitu semua jumlah populasi dijadikan sebagai responden (Sugiyono, 2017).

Metode penelitian yang digunakan adalah metode deskriptif kuantitatif dengan menggunakan alat analisis Partial Least Square (PLS), yaitu salah satu bagian dari metode alternatif Structural Equation Modelling (SEM) untuk menganalisis bagaimana pengaruh mata kuliah kewirausahaan Islam dan lingkungan terhadap terbentuknya karakter mahasantri preneur dalam diri mahasiswa (Yamin \& Kurniawan, 2011; Tanjung \& Devi, 2018), dengan menggunakan variabel independen meliputi mata kuliah kewirausahaan Islam (X1) dan lingkungan (X2), sedangkan variabel dependennya adalah mahasantri prenenur (Y1). Data penelitian dilakukan dengan cara mengirimkan kuesioner dalam bentuk google form terhadap thullab (mahasantriwan) dan thalibat (mahasantriwati) Program Studi Komunikasi dan Penyiaran Islam STIBA Ar Raayah Sukabumi yang dilaksanakan pada Desember 2020.

\section{HASIL DAN PEMBAHASAN}

Jumlah responden yang berhasil peneliti himpun sejumlah 28 orang responden saja dikarenakan masih sedikitnya jumlah mahasiswa angkatan pertama Program Studi Komunikasi dan Penyiaran Islam STIBA Ar Raayah Sukabumi, dan tidak semua mahasantri tersebut mengisi kuesioner melalui google form. Responden yang diambil merupakan mahasantri/wati aktif STIBA Ar Raayah Sukabumi yang telah mengikuti mata kuliah kewirausahaan Islam, yang dalam penelitian ini dikhususkan pada mahasantri semester lima (V) dari Program Studi Komunikasi dan Penyiaran Islam. Karakteristik umum responden yang dianalisis meliputi jenis kelamin dan usia mahasantri.

\begin{tabular}{lcc}
\multicolumn{3}{c}{ Tabel 1. Jenis Kelamin Mahasantri } \\
\hline \multicolumn{1}{c}{ Jenis Kelamin } & Jumlah & Persentase \\
\hline Laki-laki & 9 & $32,14 \%$ \\
Perempuan & 19 & $67,86 \%$ \\
\hline & $\mathbf{2 8}$ & $\mathbf{1 0 0}$ \\
\hline
\end{tabular}

Tabel di atas menunjukkan bahwa berdasarkan jenis kelamin, mayoritas responden pada penelitian ini adalah perempuan sebesar $67,86 \%$ atau sejumlah 19 orang, sedangkan laki-laki hanya sebesar $32,14 \%$ atau sebanyak 9 orang saja, karena jumlah mahasantriwati juga lebih banyak, yaitu 20 orang dan lebih banyak yang mengisi kuesioner daripada jumlah mahasantriwan yang hanya sejumlah 13 orang dan hanya 9 orang yang mengisi kuesioner.

Dalam penelitian ini usia mahasantri berada pada rentang usia 20 sampai dengan 24 tahun, berikut data usia secara rinci: 
Tabel 2. Usia Mahasantri

\begin{tabular}{lcc}
\hline \multicolumn{1}{c}{ Usia } & Jumlah & Persentase \\
\hline$\leq 20-21$ tahun & 14 & 50,00 \\
$22-23$ tahun & 11 & 39,29 \\
$\geq 24$ tahun & 3 & 10,71 \\
\hline & $\mathbf{2 8}$ & $\mathbf{1 0 0}$ \\
\hline
\end{tabular}

Peneliti juga menyeimbangkan proporsi jumlah responden dengan usia setiap mahasantri, sehingga diperoleh kesimpulan bahwa peserta terbanyak dari rentang usia $\leq 20-21$ yaitu 14 orang dengan persentase sebesar 50,00\%, diikuti rentang usia 22-23 tahun sejumlah 11 orang dengan persentase $39,29 \%$, dan terakhir rentang usia $\geq 24$ tahun hanya sejumlah 3 orang dengan persentase sebesar $10,71 \%$. Hal ini dikarenakan pihak institusi menerapkan pembatasan usia ketika masuk ke STIBA Ar Raayah Sukabumi, yaitu maksimal 21 tahun atau 3 tahun setelah menyelesaikan jenjang pendidikan SMA. Dengan usia mahasantri yang relatif masih sangat muda memungkinkan tingginya semangat mencoba hal baru di antaranya memulai bisnis dari usia muda.

Berikut merupakan uraian dan analisis hasil perilaku berwirausaha mahasantri Program Studi Komunikasi dan Penyiaran Islam STIBA Ar Raayah Sukabumi. Berdasarkan informasi yang dihimpun peneliti berikut penyajian perilaku wirausaha responden bahwa terdapat $78,1 \%$ mahasantri yang saat ini telah menjalankan usaha yang didominasi mahasantriwati, sedangkan yang belum menjalankan hanya sebesar $21,9 \%$ yang pada umumnya dari kalangan mahasantriwan. Dengan tingginya minat mahasantriwati dalam menjalankan usaha, maka diharapkan adanya pendampingan lebih lanjut untuk mengasah dan semakin mengembangkan potensi yang mereka miliki, baik oleh dosen pengampu mata kuliah maupun dukungan institusi.

Berdasarkan hasil observasi peneliti mahasantri/wati memiliki ketertarikan yang beragam dalam menjalankan usahanya, baik berupa jasa, dagang maupun kombinasi keduanya meskipun masih dijalankan secara sederhana, yang dipasarkan baik secara online, offline maupun gabungan antara keduanya. Di antara bentuk usaha mahasantri yang diuraikan dalam bentuk persentase, yaitu persentase sebesar 52\% didominasi pada bentuk usaha lainnya, seperti mereka menjadi marketer atau reseller sebuah produk dan juga ada yang menjalankan usaha jasa seperti mengajar, disusul bentuk usaha makanan dengan perolehan persentase sebesar $24 \%$, diikuti usaha makanan dan pakaian yang memiliki besaran persentase yang sama masing-masing sebesar $12 \%$.

Adapun jenis produk dari usaha yang dijalankan para mahasantri di antaranya ada yang berjualan makanan ringan berupa es krim, bakso, dan kebab mini, menjadi agen produk herbal british propolis, marketer busana muslimah celine hijab store, reseller produk kecantikan halwey, dan ada juga yang membuat stiker. Produk dan jasa yang ditawarkan tidak sedikit adalah hasil buatan sendiri atau yang lebih popular dengan istilah handmade bahkan sudah ada yang memiliki brand sendiri, seperti cute mulshoqy untuk usaha pembuatan stiker, cheap food untuk produk cemilan, zarqa's store yang khusus menjual buku yang telah ia tulis dan telah diterbitkan, dan taman al hawarey yang berfokus pada mengajar Al-Quran dan bahasa arab baik untuk kalangan anak-anak dan remaja maupun dewasa atau orang tua.

Persentase cara mahasiswa dalam memasarkan produk atau jasanya dapat diuraikan sebagai berikut, di antaranya mahasantri yang berwirauasaha secara online sebesar $8 \%$ saja dikarenakan kondisi mereka yang harus menetap di asrama membatasi untuk banyak mengakses internet, menggunakan perangkat elektronik seperti telepon seluler dan atau laptop, serta keterbatasan kuota internet. Saat ini sedikit ada kelonggaran untuk dapat mengakses perangkat 
tersebut karena dampak dari pandemi COVID-19 menyebabkan perkuliahan diselenggarakan secara daring, luring maupun gabungan antara keduanya. Sebaliknya usaha yang dijalankan secara offline cukup signifikan sebesar $40 \%$ dan yang paling besar persentasenya adalah usaha yang dijalankan dengan mengkombinasikan antara keduanya yaitu sebesar $52 \%$.

Persentase bentuk usaha mahasantri didominasi jenis usaha produk, yaitu sebesar 48\%, disusul mix antara produk dan jasa sebesar $44 \%$ dan paling sedikit hanya sebesar $8 \%$ yaitu bergerak di bidang jasa. Hal ini karena mereka menjalankan usaha di sela-sela kesibukan menjalankan kewajiban sebagai thalibul 'ilmi (penuntut ilmu syar'i) yang lebih banyak berkutat pada metode hafalan al-Quran, al-Hadist, Mutun dan kajian kitab turats (klasik). Inilah yang menjadi pembeda signifikan antara mahasiswa yang ada di perguruan tinggi berbasis pesantren dengan mahasiswa yang ada di perguruan tinggi pada umumnya.

Semua bentuk usaha mahasantri tersebut berangkat dari penugasan mata kuliah kewirausahaan Islam agar mahasiswa berani memulai menjalankan usaha meskipun dari hal sederhana, diharapkan proses pembelajaran ini dapat menumbuhkan jiwa entrepereneur dalam diri mereka dan terus dikembangkan bahkan ketika mereka telah menyelesaikan studi di pondok pesantren berbasis pendidikan perguruan tinggi ini. Hal ini juga ditunjang oleh faktor lingkungan keluarga yang sesuai dengan hasil penelitian sebelumnya yang menunjukkan bahwa anak yang terlahir dari orang tua yang bekerja sebagai wiraniagawan akan mengikuti jejak orang tuanya sebanyak lebih dari $50 \%$.

Hasil perhitungan persentase pekerjaan orang tua para mahasantri yang telah memulai berwirausaha didominasi sebagai pedagang yaitu sebesar 38,7\%, disusul pekerjaan sebagai petani sebesar 22,6\%, dan pekerjaan lainnya sebesar 19,4\% di antaranya adalah guru, dosen, da'i dan yang tidak bekerja lagi baik karena faktor usia, kondisi umur yang sudah menua dan kondisi fisik yang tidak memungkinkan lagi untuk bekerja seperti mengalami kelumpuhan atau cacat tubuh. Kemudian yang terakhir persentase orang tua mahasantri yang berprofesi sebagai PNS dan karyawan swasta memiliki besaran persentase yang sama, yaitu sama-sama 9,7\%. Berdasarkan uraian tersebut maka dapat disimpulkan bahwa kesadaran mahasantri Program Studi Komunikasi dan Penyiaran Islam STIBA Ar Raayah Sukabumi sudah bagus karena persentase yang telah memulai berbisnis di atas $50 \%$.

Nilai yang menjadi acuan dalam analisis convergent validity adalah $>0,7$ yang disebut dengan istilah dengan valid atau dalam pendapat lain nilai toleransinya $>0,5$ (Ghozali, 2014). Convergent validity merupakan langkah awal untuk melihat nilai konstruk antar komponen variabel yakni apakah komponen tersebut valid dalam mewakili variabelnya atau tidak. Dengan menggunakan nilai acuan teori tersebut hasil convergen validity dalam penelitian ini sebagai berikut: 
Tabel 3. Hasil Uji Convergent Validity

\begin{tabular}{lccc}
\hline \multirow{2}{*}{ Variabel } & Indikator & $\begin{array}{c}\text { Loading Faktor } \\
(\mathbf{> 0 , 5})\end{array}$ & Keterangan \\
\hline \multirow{3}{*}{ Mata Kuliah Kewirausahaan Islam } & X1.1 & 0,787 & Valid \\
& X1.2 & 0,713 & Valid \\
& X1.3 & 0,827 & Valid \\
& X1.4 & 0,711 & Valid \\
& X1.5 & 0,760 & Valid \\
Lingkungan & X2.1 & 0,614 & Valid \\
& X2.3 & 0,756 & Valid \\
& X2.4 & 0,762 & Valid \\
& X2.5 & 0,684 & Valid \\
& Y1.1 & 0,720 & Valid \\
Mahasantri Preneur & Y1.2 & 0,252 & Tidak Valid \\
& Y1.3 & 0,847 & Valid \\
& Y1.4 & 0,759 & Valid \\
\end{tabular}

Dari data di atas sebagian besar sudah valid atau dengan kata lain indikator-indikator dari masing-masing variabel sudah mewakili, hanya ada satu indikator yang tidak valid. Maka, ada dua hal yang bisa dilakukan yaitu berupa menghilangkan secara langsung dan memperbaiki indikator tersebut yang bisa jadi karena responden belum memahami pertanyaan dengan baik atau karena sedikitnya jumlah responden. Mata kuliah kewirausahaan Islam adalah mata kuliah baru di STIBA Ar Raayah Sukabumi khususnya pada Program Studi Komunikasi dan Penyiaran Islam. Adapun dalam penelitian ini penulis memilih untuk langsung mendelete indikator yang tidak valid yang berarti menghapus Y1.1.

Pada tahapan ini digunakan untuk menguji realibilitasnya atau menentukan tingkat akurasi dan kekonsistenan terhadap ketetapan nilai ukur didalam pengukurannya. Nilai yang menjadi acuan realibilitasnya adalah lebih besar dari 0,7 (Ghozali, 2014). Hasil uji realibilitas penelitian ini seperti berikut:

Tabel 4. Hasil Uji Discriminant Validity dan Composite Realibility

\begin{tabular}{lcc}
\hline \multicolumn{1}{c}{ Variabel } & AVE $(<\mathbf{0 , 5})$ & Composite Reliability $(>\mathbf{0 , 7})$ \\
\hline Mata Kuliah Kewirausahaan & 0,579 & 0,873 \\
Islam & 0,503 & 0,834 \\
Lingkungan & 0,688 & 0,868 \\
Mahasantri Preneur & \\
\hline
\end{tabular}

Pada tahapan ini sebagaimana Tabel 4 di atas, dapat dikemukakan bahwa semua variabel dalam penelitian ini adalah reliabel atau memiliki tingkat akurasi yang baik karena nilai AVE yang ada semuanya melebihi batas nilai minimal atau lebih besar dari 0,5. Pada nilai composite realibilitty juga masuk ke dalam kategori baik atau predictive relevance yang baik karena nilai yang ditampilkan lebih besar dari 0,7. Sehingga dapat diambil kesimpulan bahwa secara umum terdapat kesesuaian antara seluruh model pengukuran untuk variabel penelitian, yaitu mata kuliah kewairausahaan Islam, lingkungan dan mahasantri preneur adalah baik, begitu pula dengan validitas dan reliabilitasnya.

Alat analisis SEM merupakan model pendekatan alternatif dari basis kovarian menjadi basis varian bertujuan untuk menguji hubungan antara sebab akibat (Yamin \& Kurniawan, 2011). Dalam analisis data ini peneliti membuat spesifikasi model berupa rancangan inner model atau outer model. Inner model adalah struktur yang menjadi penghubung antara variabel eksogen (X) 
terhadap variabel endogen $(\mathrm{Y})$. Variabel eksogen terdiri dari mata kuliah kewirausahaan Islam (X1) yang indikatornya meliputi X1.1, X1.2, X1.3, X1.4, dan X5. Lingkungan (X2) yang indikatornya meliputi X2.1, X2.2, X2.3, X2.4, dan X2.5. Untuk variabel endogen berupa mahasantri preneur (Y1) yaitu terbentuknya karakter mahasantri preneur yang indikatornya meliputi Y1.2, Y1.3, dan Y1.4. Selanjutnya adalah melakukan proses bootsrapping untuk mengetahui nilai t-statistik atau menguji hipotesis.

Pengujian hipotesis dilakukan untuk melihat atau menguji pengaruh dari variabel eksogen (X) terhadap variabel endogen $(\mathrm{Y})$ dengan cara melihat t-statistik dari setiap angka path. Nilai ini didapatkan dengan cara melakukan uji bootstrap dengan software Smart Partial Least Square 3 (Smart PLS3) dengan tujuan meminimalkan adanya masalah dari ketidaknormalan data dalam penelitian. Angka acuan keberpengaruhan t-statitisk terhadap t-tabel untuk koefisien inner weight dari model PLS ini sebesar 1,96 dengan tingkat kepercayaan sebesar 95\%. Maksud dari angka acuan adalah jika t-statistik > t-tabel yang 1,96 berarti memiliki pengaruh yang signifikan sedangkan jika t-statistik lebih kecil dari 1,96 artinya tidak memiliki pengaruh yang signifikan. Berikut ini digambarkan pada Gambar 2 hasil dari bootsrapping menggunakan Smart PLS3.

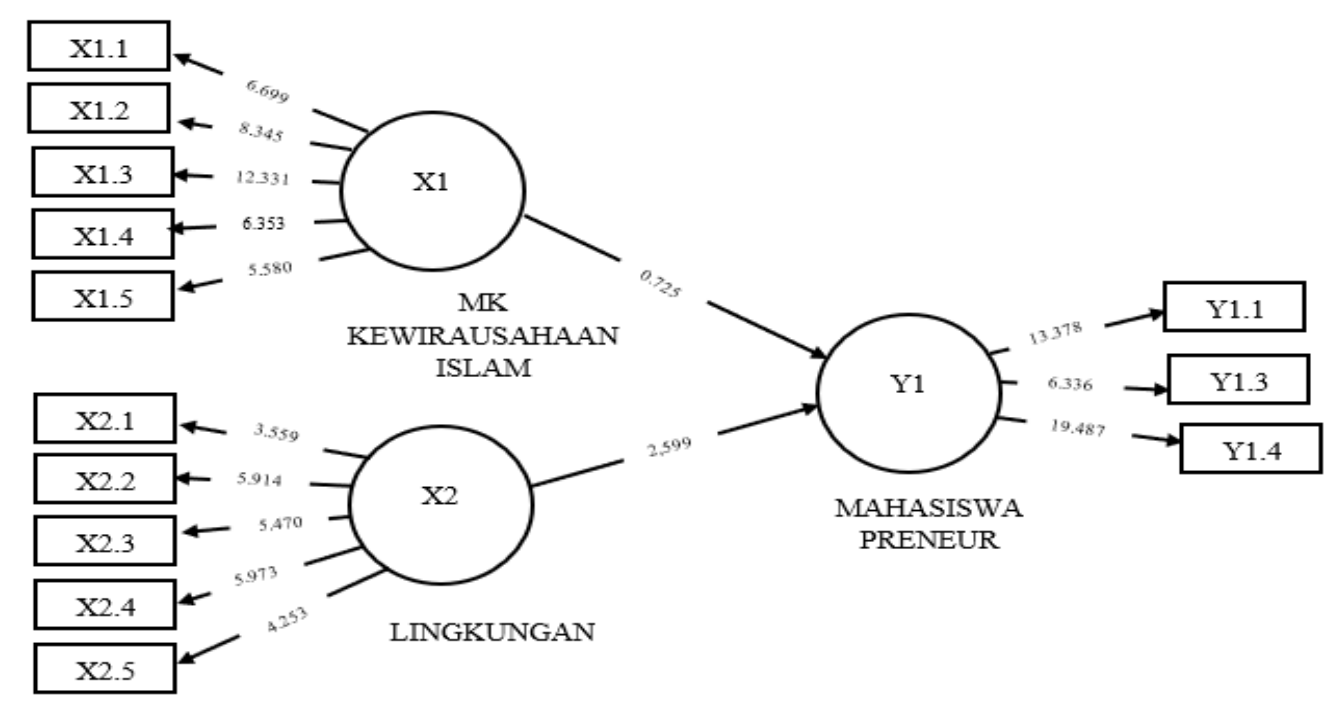

Gambar 2. Gambar Hasil Penelitian dengan melakukan Bootsrapping

Hasil pengujian hipotesis dapat dilihat sebagai berikut:

Tabel 5. Hasil Uji Hipotesis

\begin{tabular}{lccc}
\hline \multicolumn{1}{c}{ Variabel Endogen } & Variabel Eksogen & t-Statistik & P Values \\
\hline Mata Kuliah Kewirausahaan & Mahasantri Preneur & 0,725 & 0,480 \\
Islam & Mahasantri Preneur & 2,599 & 0,000 \\
Lingkungan & & \\
\hline
\end{tabular}

Dari Tabel 5 di atas, dapat dijelaskan bahwa mata kuliah aspek pertama, mata kuliah kewirausahaan Islam belum memiliki pengaruh yang signifikan terhadap pembentukan karakter mahasantri preneur pada mahasantri Program Studi Komunikasi Penyiaran Islam STIBA Ar Raayah Sukabumi karena nilai statistiknya hanya 0,725 yang artinya kurang dari batas minimal nilai acuan yaitu 1,96. Hal ini menunjukkan bahwa mata kuliah kewirausahaan Islam belum cukup untuk menumbuhkan minat mahasantri dalam berwirausaha. Mahasantri tidak langsung tertarik untuk memulai bisnis hanya dengan pemberian mata kuliah entrepreneurship semata. Hal ini sejalan dengan penelitian yang dilakukan oleh Mwatsika \& Sankhulani (2016). 
Meski mata kuliah ini tidak berpengaruh secara langsung terhadap terbentuknya karakter wirausaha dalam diri para mahasantri, namun berpengaruh terhadap lahirnya minat mereka dalam memulai wirausaha sekalipun tidak secara langsung. Maknanya bahwa minat berwirusaha akan muncul jika mereka memperoleh pembinaan selama proses perkuliahan mata kuliah kewiruausahaan Islam. Sehingga dengan adanya enterpreneur oriented ini dapat menyelaraskan antara mata kuliah ini dengan minat menjalankan bisnis sendiri. Sebaliknya, hasil penelitian ini bertolak belakang dengan beberapa hasil penelitian terkait seperti (Taufik \& Akmal, 2018; Widnyana, Widyawati \& Warmana, 2018; Fahmi \& Amanda, 2017; Rembulan, 2017) yang menyatakan bahwa mata kuliah kewirausahaan berpengaruh besar terhadap minat berwirausaha kreatif mahasiswa. Hal ini menjadi bahan evaluasi bagi dosen pengampu mata kuliah ini agar ke depannya lebih mengembangkan metode pengajarannya sehingga terbentuk pribadi mahasantri yang kelak menjadi mahasantri preneur.

Beberapa upaya yang bisa dilakukan di antaranya melakukan inovasi pembelajaran berupa pembentukan usaha bersama antara dosen dan mahasantri, mendatangkan dosen praktisi wirausaha, mengadakan seminar dan pelatihan kewirausahaan di kampus baik terhadap mahasantri maupun para asatidzah atau dosen, membuat unit kegiatan mahasiswa (UKM) yang concern pada kewirausahaan, seperti laboratorium kewirausahaan, kantin mahasiswa, dan atau koperasi mahasiswa yang memiliki struktur kepengurusan yang dikelola oleh dosen dan mahasiswa secara bersama serta diharapkan adanya dukungan birokrasi kampus. Selain itu, pemberian mata kuliah kewirausahaan Islam kepada mahasantri perlu ditingkatkan lagi kualitasnya agar terbentuk karakter mahasantri preneur dalam diri mereka. Mereka juga akan semakin terasah dalam melakukan inovasi, lebih berpikir kreatif, bahkan berani mengambil risiko yang menjadi salah satu di antara karakter utama seorang entrepreneur, sehingga memberikan evaluasi pada mata kuliah ini yang diamanahkan oleh pihak institusi khususnya Program Studi, yang saat ini dalam pelaksanaannya masih kurang efektif dalam membentuk karakter wirausaha.

Aturan institusi yang mewajibkan mahasiswa untuk lebih berfokus pada pendidikannya dalam melahirkan generasi ulama rabbani, menjadi bagian pembeda yang cukup besar antara perguruan tinggi berbasis pesantren dengan perguruan tinggi umum lainnya. Padahal dalam dien kita yang agung sudah ada qudwah dari para salafus shalih (pendahulu yang shalih), yaitu Rasululullah Shallallahu 'Alaihi Wasallam dan para sahabatnya Radhiyallahu 'Anhum 'Ajmain adalah para pedagang yang sukses di masanya, di masa keemasan peradaban Islam. Bukankah dengan berwirausaha maka dengan sendirinya para mahasantri telah mengikuti jalanya para pendahulu kita yang mulia dalam agama ini. Kemudian diharapkan mahasantri juga tidak hanya berkutat dengan teori dan hanya mengandalkan proses perkuliahan di kelas semata, namun bagaimana mereka mampu mengaplikasikannya dalam kehidupan sehari-hari, sehingga mereka telah mampu mandiri ketika di luar kampus nanti. Dengan kata lain, persentase praktek harus lebih dominan daripada pemberian teori di kelas.

Berbeda dengan aspek mata kuliah kewirausahaan Islam, aspek kedua, yaitu lingkungan berperan besar pada terbentuknya karakter preneur dalam diri mahasantri. Ini ditunjukkan dengan hasil nilai statistik sebesar 2,599 atau melebihi angka minimal nilai acuan yang besarnya 1,96. Faktor lingkungan sejalan dengan teori yang menyatakan bahwa lingkungan baik dari segi lingkungan keluarga ataupun lingkungan pendidikan berpengaruh terhadap keputusan atau minat berwirausaha (Kamal \& Thoyyibah, 2020). Hal ini karena para mahasantri dalam kesehariannya selalu berinteraksi dengan para asatidzah atau dosen yang pada umumnya menjalankan usaha. 
Mahasantri juga melihat contoh konkrit dari pimpinan pondok atau kyai yang merupakan pengusaha sukses. Selain itu, para mahasantri di dalam perkuliahan diberikan project untuk menjalankan usaha sendiri secara sederhana yang diawali dengan melakukan interview terhadap para mudarrisin dan mudarrisat (dosen) yang menjadi pelaku usaha sebelum mereka memulai usaha sendiri untuk melihat qudwah preneur para asatidz, sehingga dari proyek ini akan lahir motivasi menjadi mahasantri preneur dalam diri mereka yang kelak terlahir mahasantri preneur yang berkontribusi di tengah masyarakat setelah mereka lulus dari kampus.

Di samping lingkungan pendidikan, lingkungan keluarga turut andil memberi pengaruh terhadap minat berwirausaha mahasantri karena pada umumnya latar belakang keluarga datang dari kalangan pebisnis, seperti yang dikemukakan oleh Yoon, Tong \& Loy (2011) dan Pujiastuti \& Filantrovi (2018). Hasil penelitian menunjukkan bahwa mahasantri pada umumnya berasal dari keluarga yang menjalankan usaha sendiri atau wirausahawan. Dari hal ini diharapkan akan terlahir generasi muslim yang aktif berkontribusi di tengah masyarakat dengan menciptakan lapangan kerja dan bukan hanya berorientasi menjadi pencari kerja atau pegawai di sekor pemerintahan dan atau swasta yang turut mengambil peran dalam memajukan ekonomi umat sebagaimana manifestasi output dari perguruan tinggi (Pratiwi \& Wardana, 2016; Monica \& Rahmat, 2017; Febrianto, 2013).

\section{SIMPULAN DAN REKOMENDASI}

Dari uraian hasil penelitian di atas dapat disimpulkan bahwa mata kuliah kewirausahaan Islam di perguruan tinggi berbasis Pesantren STIBA Ar Raayah Sukabumi tidak berpengaruh besar terhadap terbentuknya karakter mahasantri preneur dalam diri para mahasantri. Hal ini menjadi bahan evaluasi bagi dosen pengampu untuk lebih mengoptimalkan proses perkuliahan dengan melakukan kreativitas dan inovasi yang dapat mendorong semangat berwirausaha para peserta didik. Sebaliknya, faktor lingkungan mampu memberikan kontribusi besar dalam melahirkan motivasi dan karakter mahasantri preneur pada peserta didik, hal ini karena mereka melihat contoh konkrit serta qudwah (teladan) wiraniagawan sukses para asatdizah (dosen) yang senantiasa berinteraksi dengan mereka dalam kesehariannya baik di dalam maupun luar kelas. Selain itu, mereka pada umumnya berasal dari background keluarga yang berprofesi sebagai wirausahawan sehingga semakin memperkuat terciptanya pribadi enterepreneuer dalam diri mahasantri.

Keterbatasan dalam penelitian ini yaitu jumlah mahasiswa yang menjadi responden hanya sedikit karena hanya dilakukan pada satu angkatan dan Program Studi, yaitu angkatan pertama Program Studi Komunikasi Penyiaran Islam, terlebih lagi yang mengisi kuesioner hanya 28 mahasantri dari total 33 mahasantri yang memprogram mata kuliah kewirausahaan Islam. Hasil yang ditemukan akan lebih maksimal jika jumlah responden juga maksimal karena akan berpengaruh terhadap hasil yang akan lebih bervariasi. Kondisi ini juga dapat menjadi masukan bagi institusi pendidikan tempat peneliti mengabdi untuk memberikan mata kuliah kewirausahaan Islam terhadap prodi lainnya, yaitu pendidikan bahasa arab untuk semakin memaksimalkan tujuan perguruan tinggi melahirkan alumni yang mampu berkontribusi di bidang pemberdayaan ekonomi umat. Melihat berbagai sisi dalam penelitian ini, maka untuk selanjutnya akan lebih baik dilakukan penelitian mendalam mengenai proses perkuliahan dan tingkat keberhasilan usaha yang dijalankan para peserta didik, bagaimana proses kolaborasi antara dosen pengampu mata kuliah dan mahasantri dalam menjalankan usaha serta sejauh mana institusi turut andil dalam mendorong lahirnya mahasantri preneur dalam lingkungan pesantren yang berbasis perguruan tinggi. 


\section{DAFTAR PUSTAKA}

Aidha, Z. (2016). Pengaruh Motivasi terhadap Minat Berwirausaha Mahasiswa Fakultas Kesehatan Masyarakat Universitas Islam Negeri Sumatera Utara. Jurnal Jumantik, 1(1), 42-59.

Al-Quran Cordoba Special for Muslimah. (2018). Bandung: PT Cordoba Internasional Indonesia.

Bahri. (2018). Kewirausahaan Islam: Penerapan Konsep Berwirausaha dan Bertransaksi Syariah dengan Metode Dimensi Vertikal (Hablumminallah) dan Dimensi Horizontal (Hablumminannas). Maro: Jurnal Ekonomi Syariah Dan Bisnis, 1(2), 67-86. Retrieved from http://jurnal.unma.ac.id/index.php/Mr/index

Dumasari. (2014). Kewirausahaan Petani dalam Pengelolaan Bisnis Mikro di Pedesaan. Jurnal Inovasi dan Kewirausahaan, 3(3), 196-202.

Fahmi, R., \& Amanda, T. (2017). Pengaruh Pembelajaran Kewirausahaan terhadap Minat Berwirausaha Mahasiswa. Jebi (Jurnal Ekonomi Dan Bisnis Islam), 2(1), 33-43.

Fauzia, I. Y. (2019). Islamic Entrepreneurship Kewirausahaan Berbasis Pemberdayaan. Depok: Rajawali Pers.

Febrianto. (2013). Analisis Minat Berwirausaha Mahasiswa STIE Lampung Timur. Jurnal Manajemen dan Bisnis, 3(2), 150-159. Retrieved from http://jurnal.ubl.ac.id/index.php/jmb/article/view/600

Ghozali, I. (2014). Structural Equation Modeling Metode Alternatif dengan Partial Least Square (PLS) dilengkapi Software Smartpls 3.0 Xlstat 2014 dan WarpPLS 4.0. Semarang: Badan Penerbit Universitas Diponegoro.

Haryani, S. (2017). Pengaruh Lingkungan Kewirausahaan terhadap Pengembangan Wirausaha di Kabupaten Sleman. EKUITAS (Jurnal Ekonomi dan Keuangan), 1(1), 24.

Jumaedi, H. (2012). Hubungan Karakteristik Wirausaha terhadap Keberhasilan Usaha (Studi Kasus pada Pengusaha Kecil di Pekalongan ). Manajerial, 11(21), 13-19.

Kamal, A. H., \& Thoyyibah, N. (2020). Analisis Faktor-Faktor Yang Mempengaruhi Minat Berwirausaha Santri Pondok Pesantren. At-Taqaddum, 12(1), 75-90.

Koranti, K. (2013). Analisis Pengaruh Faktor Eksternal dan Internal terhadap Minat Berwirausaha. Proceeding PESAT, 5, 1-7.

Maisaroh, T. (2019). Perintisan Kewirausahaan Berbasis Pesantren Melalui Pelatihan dan Pendampingan Kewirausahaan pada Santri PP Ar Risalah Mlangi Yogyakarta. JAMALIJurnal Abdimas Madani dan Lestari, 01(01), 34-40.

Monica, N., \& Rahmat, H. (2017). Faktor-Faktor Motivasi yang Mempengaruhi Mahasiswa terhadap Minat Berwirausaha (Studi pada Mahasiswa Kelas Reguler Pagi Politeknik Negeri Batam). Journal of Applied Business Administration, 1(1), 139-146.

Mufti, A. (2016). Kewirusahaan Ditinjau dari Persfektif Islam. Rasail, 8(1), 55-71.

Muliana. (2017). Konsep Dakwah Entrepreneur Menurut Abdurrahman Bin Auf. Al-Idarah: Jurnal Manajemen dan Administrasi Islam, 1(2), 227.

Munif, M., \& Baharun, H. (2018). Perguruan Tinggi Berbasis Pesantren: Menggagas Interkoneksi Agama dan Sains. Jurnal Penelitian, 12(1), 137-159.

Mustafa, M. B., Bistamam, M. N., Arep, M. A. S. M., Latip, N. A. B. M., \& Jais, S. M. (2019). Factors Stimulating Students to Venture into The Field of Entrepreneurship Towards Producing Entrepreneurs Among University Students. International Journal of Academic Research in Business and Social Sciences, 9(3), 875-883. 
Mwatsika, C., \& Sankhulani, E. (2016). Effect of Entrepreneurship Education on Students Orientation Towards Entrepreneurship at the Malawi Polytechnic. International Journal of Business and Economics Research, 5(6), 235-245.

Periera, A., Mashabi, N. A., \& Muhariati, M. (2017). Pengaruh Dukungan Orangtua terhadap Minat Anak dalam berwirausaha (Pada Siswa SMK Strada Koja, Jakarta Utara). JKKP (Jurnal Kesejahteraan Keluarga dan Pendidikan), 4(02), 70-76.

Prastyaningtyas, E. W., \& Arifin, Z. (2019). Pentingnya Pendidikan Kewirausahaan pada Mahasiswa dengan Memanfaatkan Teknologi Digital sebagai Upaya Menghadapi Revolusi 4.0. Proceedings of the ICECRS, 2(1), 281-285.

Praswati, A. N. (2014). Analisis Faktor-Faktor yang Mempengaruhi Minat Wirausaha di Kalangan Mahasiswa Studi Kasus: Fakultas Ekonomi dan Bisnis Universitas Muhammadiyah Surakarta. Seminar Nasional dan Call for Paper (Sancall 2014), (Sancall), 134-142. Retrieved from https://publikasiilmiah.ums.ac.id/xmlui/handle/11617/4647

Pratiwi, Y., \& Wardana, I. (2016). Pengaruh Faktor Internal dan Eksternal terhadap Minat Berwirausaha Mahasiswa Fakultas Ekonomi dan Bisnis Universitas Udayana. E-Jurnal Manajemen Unud, 5(8), 5215-5242.

Pujiastuti, Y., \& Filantrovi, E. W. (2018). Gambaran Minat Kewirausahaan Mahasiswa (Studi terhadap Mahasiswa STIE Bank BPD Jateng ). Jurnal Manajemen, 15(2), 169-180.

Rahmadi, A. N., \& Heryanto, B. (2016). Analisis Faktor-Faktor yang Mempengaruhi Minat Berwirausaha pada Mahasiswa Program Studi Manajemen Fakultas Ekonomi Universitas Kadiri. Ekonika : Jurnal Ekonomi Universitas Kadiri, 1(2), 153-169.

Ramadhani, N. T., \& Nurnida, I. (2017). Pengaruh Mata Kuliah Kewirausahaan terhadap Minat Berwirausaha Mahasiswa. Jurnal Ecodemica, 1(1), 89-97.

Ranto, D. W. P. (2017). Pengaruh Entrepreneurial Traits terhadap Intensi Kewirausahaan. JBTI: Jurnal Bisnis Teori dan Implementasi, 8(1), 36-44.

Rembulan, G. D. (2017). Pengaruh Pendidikan Kewirausahaan terhadap Minat Berwirausaha. Jurnal Pengabdian dan Kewirausahaan, 1(1), 65-73.

Rinawiyanti, E. D., \& Gunawan, L. H. (2017). Identifikasi Faktor Pemicu Minat Wirausaha pada Mahasiswa. Forum Bisnis dan Kewirausahaan Jurnal Ilmiah STIE MDP , 7(1), $27-42$.

Risdiana, A. (2014). Transformasi Peran Da'i dalam Menjawab Peluang dan Tantangan (Studi terhadap Manajemen SDM). Jurnal Dakwah, XV(2), 433-451. Retrieved from http://ejournal.uin-suka.ac.id/dakwah/jurnaldakwah/article/view/315

Saragih, R. (2017). Membangun Usaha Kreatif. Jurnal Kewirausahaan, 3(2), $26-34$.

Setyawan, C. E. (2016). Menggagas Model Perguruan Tinggi Agama Islam Berbasis Pesantren. Jurnal Komunikasi dan Pendidikan Islam, 5(1), 99-130.

Sharaf, A., El-Gharbawy, A., \& Ragheb, M. A. (2018). Factors That Influence Entrepreneurial Intention within University Students in Egypt. Open Access Library Journal, 5(10), 1-14.

Sugita, S., \& Ansori, A. (2018). Upaya Dosen Kewirausahaan sebagai Faktor Determinatif dalam Menumbuhkan Motivasi Wirausaha Mahasiswa IKIP Siliwangi. Comm-Edu (Community Education Journal), 1(2), 127-137.

Sugiyono. (2017). Metode Penelitian Bisnis: Pendekatan Kuantitatif, Kualitatif, Kombinasi, dan $R \& D$. Bandung: CV. Alfabeta.

Suryana. (2014). Kewirausahaan: Kiat dan Proses Menuju Sukses. Jakarta: Salemba Empat. 
Susilaningsih. (2015). Pendidikan Kewirausahaan di Perguruan Tinggi: Pentingkah untuk Semua Profesi. Jurnal Economica, 11(1), 1-9.

Tanjung, H., \& Devi, A. (2018). Metodologi Penelitian Ekonomi Islam Edisi ke 2. Bekasi: Gramata Publishing.

Taufik, A., \& Akmal. (2018). Peran Mata Kuliah Kewirausahaan dalam Menumbuh- kembangkan Jiwa Enterpreneur Mahasiswa PPKn. Journal of Civic Education, 1(4), 343-349.

Widnyana, I. W., Widyawati, S. R., \& Warmana, G. O. (2018). Pengaruh Pemberian Mata Kuliah Kewirausahaan dan Pelatihan Wirausaha terhadap Minat Wirausaha Ekonomi Kreatif pada Mahasiswa Unmas Denpasar. Jurnal Bakti Masyarakat Indonesia, 1(1), 171-177.

Widodo, S., \& Nugroho, T. R. D. (2014). Model Pendidikan Kewirausahaan bagi Santri untuk Mengatasi Pengangguran di Pedesaan. Mimbar, 30(2), 171-179. Retrieved from http://ejournal.unisba.ac.id/index.php/mimbar/article/view/704

Yamin, S., \& Kurniawan, H. (2011). Generasi Baru Mengolah Data Peneltian dengan Partial Least Square Path Modeling. Depok: Penerbit Salemba Infotek.

Yoon, D., Tong, K., \& Loy, L. C. (2011). Factors Influencing Entrepreneurial Intention Among University Students. International Journal of Social Sciences and Humanity Studies, 3(1), 487-496. 